\title{
Overview and status of the prototype project for Wendelstein 7-X control system
}

\author{
*Jörg Schacht ${ }^{\mathrm{a}}$, Torsten Bluhm ${ }^{\mathrm{a}}$, Uwe Herbst ${ }^{\mathrm{a}}$, Christine Hennig ${ }^{\mathrm{a}}$, Stefan Heinrich ${ }^{\mathrm{a}}$, Georg \\ Kühner $^{\mathrm{a}}$, Erik Köster ${ }^{\mathrm{a}}$, Heike Laqua $^{\mathrm{a}}$, Marc Lewerentz ${ }^{\mathrm{a}}$, Mirco Marquardt ${ }^{\mathrm{a}}$, Christiane Meyer ${ }^{\mathrm{a}}$, \\ Ina Müller ${ }^{\mathrm{a}}$, Steffen Pingel ${ }^{\mathrm{a}}$, Jürgen Sachtleben ${ }^{\mathrm{a}}$, Anett Spring ${ }^{\mathrm{a}}$, Andreas Werner ${ }^{\mathrm{a}}$, Andreas \\ Wölk $^{\mathrm{a}}$ \\ ${ }^{a}$ Max-Planck-Institut für Plasmaphysik, EURATOM Association, Teilinstitut Greifswald, \\ Wendelsteinstraße 1, D-17491 Greifswald, Germany \\ * Corresponding author; Tel.: +49-3834-88-2761; Fax: +49-3834-88-2509; \\ E-mail address: Joerg.Schacht@ipp.mpg.de
}

\section{Abstract}

This contribution gives an overview of the project "Prototype W7-X control system”. The objective of this prototype project is to demonstrate the applicability of the segment orientated control system at a running fusion experiment including steady state operation, interaction of all relevant components, real time control, data acquisition and on-line data analysis.

Furthermore, the W7-X safety concept will be implemented at WEGA and tested.

The project was started in October 2006 and will be finished in March 2010.

After a short description of the stellarator WEGA the project organization, the implementation of the new W7-X like control system, and first tests results will be discussed. An outlook summarizes the next steps planned for project phase II.

\section{Keywords}

Wendelstein 7-X, WEGA, prototype, system test, control, safety, data acquisition 


\section{Introduction}

The control concepts for the steady state fusion experiment Wendelstein 7-X (W7-X) are designed to face the requirements in the context of flexibility, availability, maintainability, safety, scalability and physics driven experiment operation. At the moment the Wendelstein W7-X device is under construction and the commissioning is scheduled for 2014. To reach this milestone all necessary control and diagnostic components of W7-X, e.g. ECRH and NBI heating systems, the gas supply system, the magnet systems, and the cryogenic system, have to be planned, constructed and commissioned. Usually W7-X components and its control systems aren't prefabricated parts. They are prototypes, which have to be developed individually and do not rely on proven industrial technology. The segment control concept has been developed to meet the special requirements of W7-X operation, which include short pulse as well as long term discharges with up to 30 min duration. This concept is based on a hierarchical control structure with a central control system on top and subordinated control components. The behaviour of all control components is predefined by experiment programs, consisting of a chain of so called segments [3].

The Wendelstein 7-X (W7-X) is a large and complex fusion plasma experiment to investigate the physical principles underlying a nuclear fusion power plant. W7-X is a stellarator and therefore suitable for continuous operation in contrast to pulsed operated tokamak experiments.

An early demonstration of the steady state control concepts with all concerned parts of the W7-X data acquisition and control systems in a productive environment is a necessary step to optimize the control concepts and to minimize the project risk for the W7-X control system. Furthermore we want to involve the future users, e.g. experiment leaders and diagnosticians, in the process of defining workflows and designing user interfaces. For this reason the project "Prototype W7-X Control System" was founded in October 2006. The main objective of it is to implement the control and the safety concepts of W7-X at the small fusion experiment WEGA.

\section{Stellarator WEGA as testbed}

The physics department of the Max-Planck-Institut für Plasmaphysik in Greifswald operates WEGA since 2001. WEGA is a medium sized classical stellarator, mainly used for educational purposes and basic plasma research. In context of the W7-X project, the field of application of WEGA has been enlarged by using it as a testbed for W7-X diagnostic prototypes and the control system for W7-X. Fig. 1 shows a view on the machine WEGA.

The main parameters of the WEGA stellarator are the following: The plasma vessel has a circular cross-section with a major radius of $\mathrm{R}=72 \mathrm{~cm}$ and a minor radius of $\mathrm{r}=19 \mathrm{~cm}$. The maximum averaged plasma radius is $\mathrm{a}=11 \mathrm{~cm}$. The plasma volume is $0.16 \mathrm{~m}^{3}$. The gas inlet system can deliver gas species $\mathrm{He}, \mathrm{Ar}$ and $\mathrm{H}_{2}$ for experiment operation.

The magnetic configuration of WEGA can be very flexibly set by the 40 toroidal field coils, 4 helical field coils and 2 pairs of vertical field coils. The helix has a poloidal period number $\mathrm{l}=2$ and toroidal period number $\mathrm{m}=5$ configuration. For error compensation of the magnetic field configuration a separated error field compensation coil was installed. 


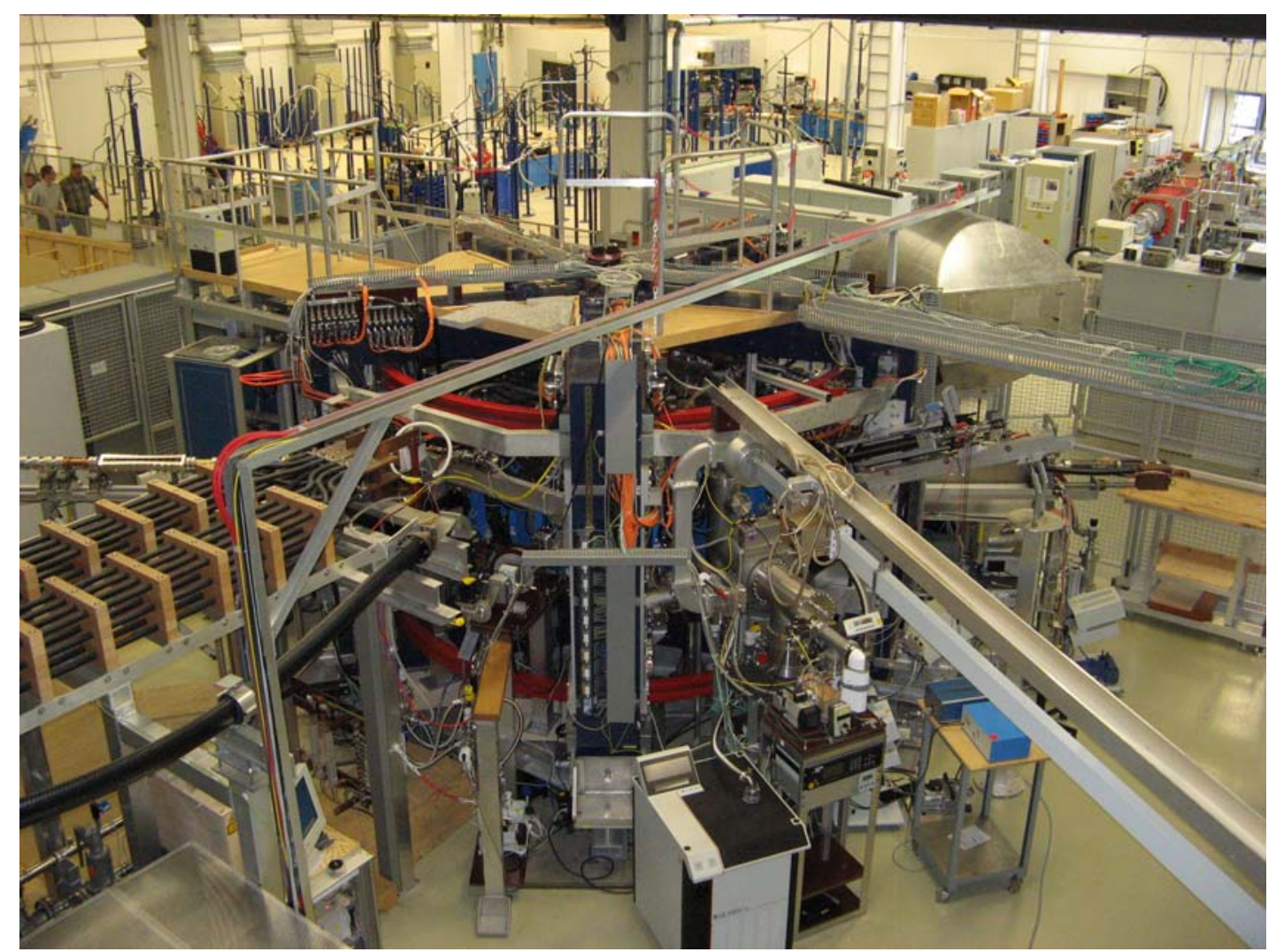

Fig. 1: The WEGA stellarator located at IPP Greifswald, Germany.

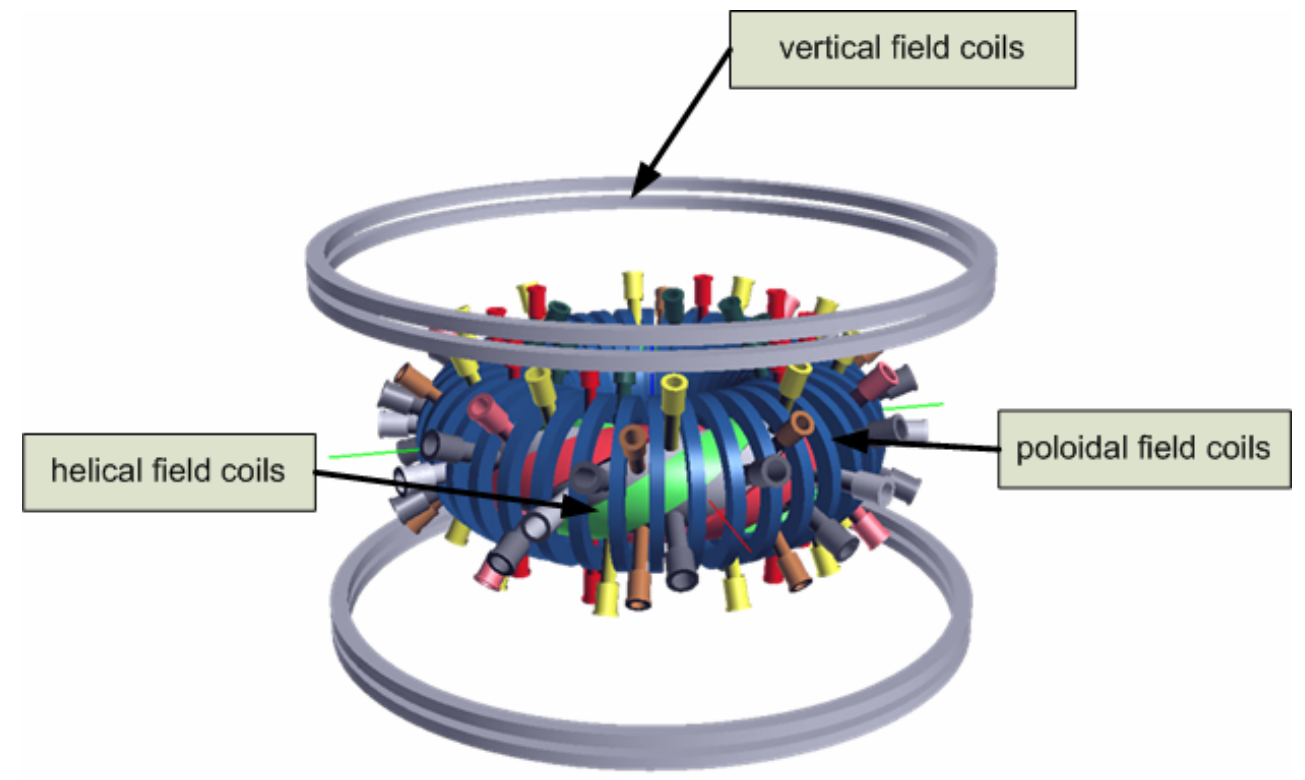

Fig. 2: The magnetic system of WEGA

All coils of magnetic system are water cooled copper coils. The main coil systems are shown in Fig. 2. The WEGA machine can be operated in both kinds: steady state up to a field strength of $\mathrm{B}=0.35 \mathrm{~T}$ and pulsed with a maximum field strength of $0.9 \mathrm{~T}$.

Two magnetrons M1 and M2 with $6 \mathrm{~kW}$ and $20 \mathrm{~kW}$, each operating at a frequency of $2.45 \mathrm{GHz}$, are used for plasma generating and heating. A $28 \mathrm{GHz}$ gyrotron with a maximum power of $10 \mathrm{~kW}$ (cw) enlarges the spectrum for plasma heating since its installation in 2006. Typical plasma discharges at WEGA achieve parameters in the order of $T_{e}=5^{-15} \mathrm{eV}$ and $\mathrm{n}_{\mathrm{e}}=10^{17}-10^{18} \mathrm{~m}^{-3}[1]$. 


\section{Prototype project overview}

In March 2005 the Design Review Data took place at IPP Greifswald. The reviewers proposed to consider the in-house fusion experiment WEGA as an advanced testbed for W7-X control and data acquisition.

The main reasons to found the prototype project are: WEGA is a running experiment allowing short pulse and steady-state operation. Essential W7-X control requirements (steady-state control, segmented device control, interaction with physics, data acquisition, heating etc., and safety concept) can be simulated at WEGA in a unified form at an early stage. In this way it is possible to directly use the results of prototype tests for the W7-X control project.

The main project objectives are the following:

- Integrated test of the concepts for control, data acquisition and real-time data processing in a W7-X like environment,

- Test of the concepts for the W7-X safety system as a part of the prototype,

- Education of personnel for design and installation of W7-X like control components and the operation of fusion experiments,

- Test and evaluation of user interfaces and tools for preparation and processing of experiment programs,

- Design, realization and test of diagnostic prototypes for W7-X.

The prototype project is divided into two main phases. Phase I started in October 2006 and was terminated end of March 2008. The second phase started in April 2008 and will last until March 2010.

The main goal of phase I was the implementation of a W7-X like control system at WEGA. All technical and diagnostic components necessary for a first segment controlled plasma operation should be realized until end of March 2008. The integration of further control components is scheduled for project phase II. The local and central components of the prototype and its time schedule and realization status are listed in Tab. 1.

After the project started, a detailed work breakdown structure (WBS) for all project tasks was prepared. The WBS contains all important steps for design, development and testing of a control component. The working packages of this WBS are based on the planned workflow for design of a W7-X control component. Table 2 summarizes and explains the main working packages for a control component.

\begin{tabular}{|l|l|l|l|l|}
\hline \multicolumn{1}{|c|}{ Type } & \multicolumn{1}{|c|}{ Component } & \multicolumn{1}{|c|}{$\begin{array}{c}\text { Project } \\
\text { phase }\end{array}$} & \multicolumn{1}{c|}{$\begin{array}{c}\text { Control system } \\
\text { type }\end{array}$} & \multicolumn{1}{|c|}{ Status } \\
\hline $\begin{array}{l}\text { Technical } \\
\text { component }\end{array}$ & Central control system & phase I & $\begin{array}{l}\text { PLC and segment } \\
\text { control system }\end{array}$ & realized \\
\hline $\begin{array}{l}\text { Technical } \\
\text { component }\end{array}$ & Safety system & phase I & safety PLC & realized \\
\hline $\begin{array}{l}\text { Technical } \\
\text { component }\end{array}$ & Supply for magnetic system & phase I & $\begin{array}{l}\text { PLC and segment } \\
\text { control system }\end{array}$ & realized \\
\hline $\begin{array}{l}\text { Technical } \\
\text { component }\end{array}$ & $\begin{array}{l}\text { Central Building Control } \\
\text { system }\end{array}$ & phase I & PLC & realized \\
\hline $\begin{array}{l}\text { Technical } \\
\text { component }\end{array}$ & Cooling system & phase I & PLC & realized \\
\hline
\end{tabular}




\begin{tabular}{|c|c|c|c|c|}
\hline $\begin{array}{l}\text { Technical } \\
\text { component }\end{array}$ & $\begin{array}{l}\text { Micro wave plasma heating } \\
\text { system }\end{array}$ & phase I & $\begin{array}{l}\text { PLC and segment } \\
\text { control system }\end{array}$ & realized \\
\hline $\begin{array}{l}\text { Technical } \\
\text { component }\end{array}$ & Machine instrumentation & phase I & PLC & realized \\
\hline $\begin{array}{l}\text { Technical } \\
\text { component }\end{array}$ & Vacuum system & phase I & PLC & realized \\
\hline $\begin{array}{l}\text { Technical } \\
\text { component }\end{array}$ & Gas injection system & phase I & $\begin{array}{l}\text { PLC and segment } \\
\text { control system }\end{array}$ & realized \\
\hline $\begin{array}{l}\text { Operational } \\
\text { diagnostic }\end{array}$ & Interferometry & phase I & $\begin{array}{l}\text { PLC and segment } \\
\text { control system }\end{array}$ & realized \\
\hline Diagnostic & SOPRA Echelle spectroscope & phase I & $\begin{array}{l}\text { PLC and segment } \\
\text { control system }\end{array}$ & realized \\
\hline $\begin{array}{l}\text { Technical } \\
\text { component }\end{array}$ & $\begin{array}{l}\text { Implementation of Gyrotron in } \\
\text { micro wave plasma heating } \\
\text { system }\end{array}$ & phase II & $\begin{array}{l}\text { PLC and segment } \\
\text { control system }\end{array}$ & under construction \\
\hline Diagnostic & Magnetics & phase II & $\begin{array}{l}\text { PLC and segment } \\
\text { control system }\end{array}$ & under construction \\
\hline Diagnostic & Neutral gas measurement & phase II & $\begin{array}{l}\text { PLC and segment } \\
\text { control system }\end{array}$ & under construction \\
\hline Diagnostic & $\mathrm{H}$ alpha measurement & phase II & $\begin{array}{l}\text { PLC and segment } \\
\text { control system }\end{array}$ & 2009 \\
\hline Diagnostic & General purpose diagnostic & phase II & $\begin{array}{l}\text { PLC and segment } \\
\text { control system }\end{array}$ & 2009 \\
\hline Diagnostic & $\begin{array}{l}\text { Integration of established } \\
\text { WEGA diagnostics }\end{array}$ & phase II & $\begin{array}{l}\text { PLC and segment } \\
\text { control system }\end{array}$ & 2009 \\
\hline Diagnostic & Video diagnostics & phase II & $\begin{array}{l}\text { PLC and segment } \\
\text { control system }\end{array}$ & 2009 \\
\hline \multicolumn{5}{|l|}{ Optional: } \\
\hline Diagnostic & $\begin{array}{l}\text { Bolometry, } \\
\text { Heavy Ion beam probe, } \\
\text { Langmuir probes, } \\
\text { X-ray diagnostics }\end{array}$ & phase II & $\begin{array}{l}\text { PLC and segment } \\
\text { control system }\end{array}$ & 2009 \\
\hline
\end{tabular}

Tab. 1: Components of prototype

\begin{tabular}{|l|l|l|}
\hline \multicolumn{1}{|c|}{ WBS task } & \multicolumn{1}{|c|}{ Sub task } & \multicolumn{1}{c|}{ Description } \\
\hline $\begin{array}{l}\text { Functional specification } \\
\text { control system }\end{array}$ & Write specification & $\begin{array}{l}\text { On base of a template the structure and the behavior of } \\
\text { the component has to be specified, e.g. all control } \\
\text { functions and operational states, the control system } \\
\text { structure, safety aspects and the interface. }\end{array}$ \\
\cline { 2 - 3 } & Update project plan (WBS) & $\begin{array}{l}\text { The working packages of the WBS have to be worked } \\
\text { out in detail. Time and personnel resources must be } \\
\text { connected with the packages. }\end{array}$ \\
\hline Safety analysis & $\begin{array}{l}\text { Make a risk analysis and } \\
\text { evaluation. }\end{array}$ & $\begin{array}{l}\text { For every component with potential hazards for } \\
\text { environment or for personnel it is necessary to analyze } \\
\text { safety aspects. Activ and passiv safety protection } \\
\text { systems, the safety interface to the central safety system, }\end{array}$ \\
\hline
\end{tabular}




\begin{tabular}{|c|c|c|}
\hline & & and the safety control functions has to be defined. \\
\hline \multirow[t]{3}{*}{$\begin{array}{l}\text { Slow control \& } \\
\text { operational management }\end{array}$} & PLC software setup & $\begin{array}{l}\text { The component PLC is responsible for the operational } \\
\text { management and dedicated control functions. }\end{array}$ \\
\hline & Hardware installation and cabling & $\begin{array}{l}\text { Design, plan and realize electrical cabinets, cable } \\
\text { routing, networks and others. }\end{array}$ \\
\hline & $\begin{array}{l}\text { Visualization: } \\
\text { - WinCC operator station } \\
\text { hardware setup } \\
\text { - WinCC operator station } \\
\text { software setup }\end{array}$ & $\begin{array}{l}\text { The human - machine interface (HMI) of the } \\
\text { components operational management is based on the } \\
\text { application WinCC (Fa. Siemens). A layout for } \\
\text { visualization has to be developed. Hard - and software } \\
\text { must be installed. }\end{array}$ \\
\hline \multirow[t]{3}{*}{ Segment control } & $\begin{array}{l}\text { CS (FCS or DAQ station) } \\
\text { hardware setup }\end{array}$ & $\begin{array}{l}\text { The control stations (CS) for data acquisition and fast } \\
\text { control have to be assembled. }\end{array}$ \\
\hline & $\begin{array}{l}\text { CS (FCS or DAQ station) } \\
\text { software setup }\end{array}$ & $\begin{array}{l}\text { The control stations have to be equipped with standard } \\
\text { and special software. }\end{array}$ \\
\hline & Hardware installation and cabling & $\begin{array}{l}\text { Design, planning and realization of the integration of } \\
\text { control stations into the electrical cabinets, cable } \\
\text { routing, network connections and others. }\end{array}$ \\
\hline Test of component & $\begin{array}{l}\text { - Test operational management } \\
\text { and slow control } \\
\text { - Test segment control system } \\
\text { - Test of safety system }\end{array}$ & $\begin{array}{l}\text { All parts of the control component have to be tested } \\
\text { before the system is ready for integration into the } \\
\text { prototype control system. Every test procedure is } \\
\text { planned and documented using test protocols. }\end{array}$ \\
\hline $\begin{array}{l}\text { Test of control system is } \\
\text { finished }\end{array}$ & $\begin{array}{l}\text { The component is ready for } \\
\text { integration into the prototype } \\
\text { (WEGA) control system. }\end{array}$ & Milestone \\
\hline
\end{tabular}

Tab. 2: Major WBS points for design, construction and test of a component

An overview about the prototype control system and its local control components is given in [2]. Major concepts of W7-X control systems are described in [3][4][5][6][7][8]. All components modified in phase I were extensively tested in autonomous mode. These tests covered the safety interfaces, the operational management and the local segment operation. An example for the visualization of a component is shown in Fig. 3.

Integral tests of prototype control system and experiment operation have been started at the beginning of phase II in April 2008.

Project phase II is foreseen for an extensive testing of the segment control system and the safety system during a technically and physically motivated experimental program at WEGA. Furthermore the design and implementation of further W7-X diagnostic prototypes (listed in Tab.2) are under construction or are planned.

After the W7-X like control system showed that it operates flawlessly at WEGA extensive tests of different parts of the control system have been started. Key aspects of these tests are the safety system, segment planning and experiment operation using the segment control system for WEGA standard scenarios. Examples for realized experiment programs and its main parameters are listed in Tab. 3. A detailed explanation for an assortment of test experiments and its segment programming is given in [9]. 


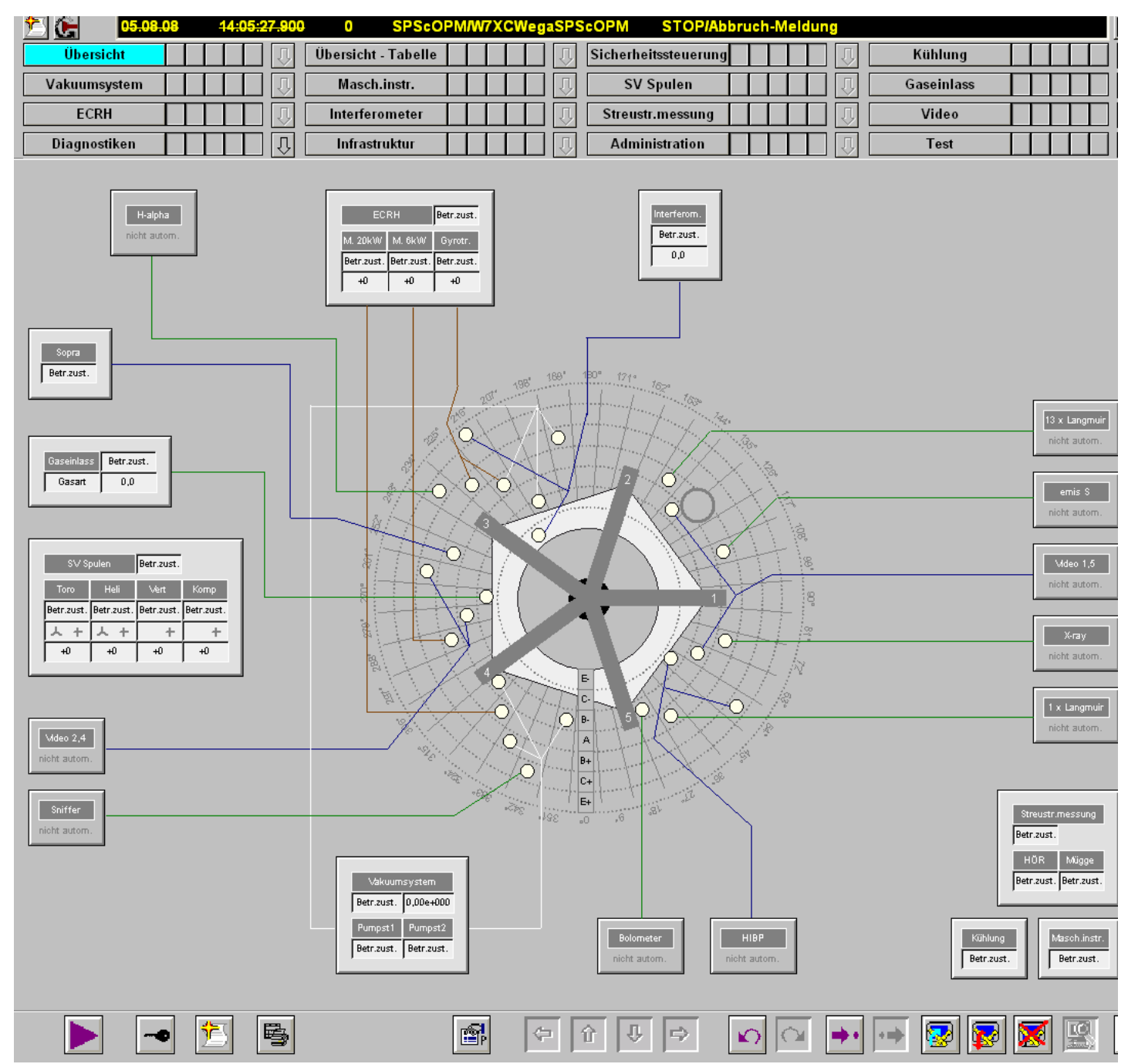

Fig. 3: Visualization of central operational management of prototype

\begin{tabular}{|c|c|c|c|}
\hline $\begin{array}{c}\text { Experiment } \\
\text { type }\end{array}$ & Main parameters & $\begin{array}{l}\text { Discharge } \\
\text { time }\end{array}$ & $\begin{array}{l}\text { Control and data } \\
\text { acquisition components }\end{array}$ \\
\hline Standard discharge 0 & $\begin{array}{l}1 \text { experiment scenario in a discharge: } \\
\text { (1) Plasma start up with the M2 } \\
\text { (2) Experiment phase: Heating only with M2 } \\
\text { magnetron, } \\
\text { (3) Post processing. } \\
\text { - Heating: Magnetron M2 with } 1.8 \mathrm{~kW} \text { power, } \\
\text { - Gas sort: Argon or Helium, } \\
\text { - } \quad \text { B0 }=58 \mathrm{mT} \text { to } 52 \mathrm{mT} \text {, }\end{array}$ & $35 \mathrm{~s}$ & \multirow{2}{*}{$\begin{array}{l}\text { magnet supplies, } \\
\text { cooling system, } \\
\text { machine instrumentation, } \\
\text { ECRH, } \\
\text { interferometry, } \\
\text { spectroscopy, } \\
\text { magnetics, } \\
\text { central segment sequence } \\
\text { control, } \\
\text { safety system, } \\
\text { central operational } \\
\text { management }\end{array}$} \\
\hline Standard discharge 1 & $\begin{array}{l}1 \text { experiment scenario in a discharge: } \\
\text { (1) Plasma start up with the M1 } \\
\text { (2) Experiment phase: Heating only with M1 } \\
\text { magnetron, } \\
\text { (3) Post processing. } \\
\text { - Heating: Magnetron M1 with } 6 \mathrm{~kW} \text { power, } \\
\text { - Gas sort: Argon or Helium, }\end{array}$ & $35 \mathrm{~s}$ & \\
\hline
\end{tabular}




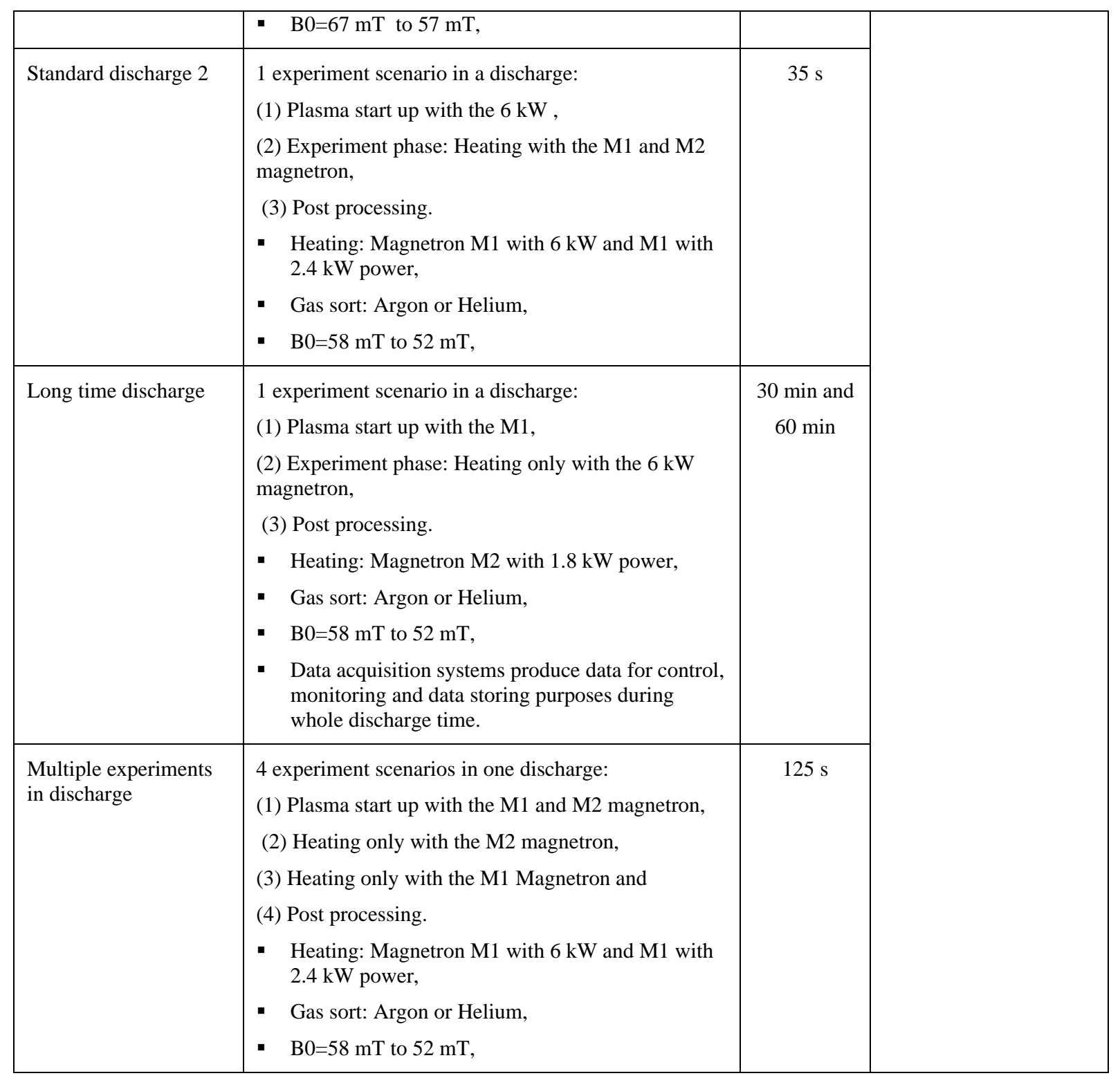

Tab. 3: Assortment of test experiment programs at prototype

\section{Conclusions}

The results of the first integral test phase for the control and safety system are very positive. All planned types of operations planned for W7-X can be fulfilled within the initial concepts. The defined workflows for design and realization of control components are useful and cover the requirements fully. During the realization of the prototype it was possible to collect very important experiences on different areas, e.g. implementation of safety technics or design of user interfaces. Especially the plasma experiments operated by the segment control system have shown the flexibility and the capability of the segment control concepts for short pulse experiments as well as for long pulse experiments. As a drawback it was identified that the existing segment editor has performance problems and is not comfortable when editing complex experiment programs. A more adequate experiment program editor is under development.

A very important aspect of phase II is to train personnel in the use of the new control tools. In this context the future users of the control system (physicists and experiment leaders) are able to evaluate the user interfaces of the specialized tools (e.g. segment editor, session leader 
program Xcontrol, notification system, monitor program, data browser) which have been developed for W7-X operation.

\section{Outlook and acknowledgement}

This paper gives an overview about the content and course of the project "Prototype W7-X control system”. Reusing the stellarator WEGA as an integrated testbed is the most important activity for the preparation and realization of control projects for W7-X.

Besides the continuing work at the prototype on the technical level the prototype project activities have to focus the topics experiment preparation (tools and workflow) and experiment program planning.

Many colleagues are directly or indirectly involved with the work for the prototype project. Special thanks go to the members of the project team, of the technical services, and the electronics division.

\section{References}

[1] K. Horvath, J. Lingertat, M. Otte, and Friedrich Wagner, Investigations of the electron temperature profiles at the WEGA stellarator Plasma Phys. Control. Fusion 48 (2006) 315323

[2] J. Schacht, et al., Stellarator WEGA as a test-bed for the WENDELSTEIN 7-X control system concepts

Fusion Eng Des (2008), Volume 83, issues2-3, April 2008

[3] J. Schacht, H. Laqua, M. Lewerentz, I. Müller, S. Pingel, A. Spring and A. Wölk, Overview and status of the control system of WENDELSTEIN 7-X

Fusion Engineering and Design, Volume 82, Issues 5-14, October 2007, Pages 988-994

[4] A. Spring, H. Laqua and J. Schacht, User control interface for W7-X plasma operation, Fusion Engineering and Design, Volume 82, Issues 5-14, October 2007, Pages 1002-1007

[5] A. Spring, H. Laqua and H. Niedermeyer, User interaction concept for plasma discharge control on WENDELSTEIN 7-X, Fusion Engineering and Design, Volume 81, Issues 1517, July 2006, Pages 1957-1961

[6] J. Schacht, H. Niedermeyer, C. Wiencke, J. Hildebrandt, A. Wassatsch, A trigger-timeevent system for the W7-X experiment

Fusion Engineering and Design, Volume 60, Issue 3, June 2002, Pages 373-379

[7] J. Schacht, H. Laqua, M. Lewerentz and A. Spring, Standardized communication in the control system of the experiment WENDELSTEIN 7-X, IEEE Transactions on Nuclear Science. 55(1 Part 1):322-327, 2008 Feb.

[8] P. Heimann, et al., Status report on the development of the data acquisition system of Wendelstein7-X, Fusion Engineering and Design, Volume 71 (2004), Pages 219-224. 
[9] M. Lewerentz at al., First experiences with the new W7-X like control system at the WEGA Stellarator, SOFT conference, Rostock, Sept.2008 